\title{
The development and implementation of an android-based saving and loan cooperative application
}

\author{
Moechammad Sarosa', Devi Khanthi Dwi Bhakti ${ }^{2}$, Putri Elfa Mas'udia ${ }^{3}$, Yunia Mulyani Azis ${ }^{4}$, Nailul \\ Muna $^{5}$, Ekananda Sulistyo Putra ${ }^{6}$ \\ 1,2,3,5,6 Department of Electrical Engineering, State Polytechnic of Malang, Indonesia \\ ${ }^{4}$ STIE Ekuitas Bandung, Indonesia
}

\section{Article Info}

Article history:

Received Jul 31, 2021

Revised Sep 12, 2021

Accepted Oct 15, 2021

\section{Keywords:}

Android applications

Hypertext preprocessor MySQL

Savings and loan applications Savings and loan cooperatives

\begin{abstract}
The savings and loans cooperative are a cooperative that has an important purpose in its reach and services, such as the Permata Ngijo Savings and Loans Cooperative. Activities within the cooperative itself include managing member data as well as savings and loan transactions. In systems that are still manual, such as Microsoft Excel, there is a risk of inaccurate data and takes a long time. This manual system is still less effective because the number of members and transactions continues to grow. Therefore, an application is needed as a more effective data processing and information system for members that is easier to access. This study aims to build an android-based savings and loan application using the hypertext preprocessor (PHP) programming language and my structured query language (MySQL) as data storage. Based on the android application that has been made, it shows that the black box functionality of the application runs as planned, the success rate for users reaches $90 \%$.
\end{abstract}

This is an open access article under the CC BY-SA license.

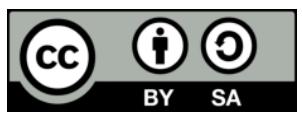

\section{Corresponding Author:}

Nailul Muna

Department of Electrical Engineering

State Polytechnic of Malang

Jl. Soekarno-Hatta No. 9, Malang 65141, Indonesia

Email: nailulmuna@polinema.ac.id

\section{INTRODUCTION}

A cooperative is a financial institution whose members are cooperative people or legal entities. The history of savings and loan cooperatives is inseparable from the development of cooperatives in the country. The basis of its activities is to provide community services that help increase working capital and invest money for the community. Savings and loan cooperatives are cooperatives with savings and loan services for their members. So that members can save and raise their capital and can lend funds to cooperatives for business capital. Savings and loan cooperatives are the goal of micro-entrepreneurs as a source of financing with a fast process and low-interest rates. The savings and loan business that is the foundation of the cooperative will survive and continue to grow [1]-[3]. Currently, information technology has a rapid development in various fields of life [4]. This encourages an organization or company to use information technology according to the level of needs and objectives. The development of information technology in Indonesia in the field of savings and loans such as cooperatives can be seen from the data management process and savings and loan transactions from members [5]. Information technology plays a role in recording, storing, and processing data [6]. But not all cooperatives in Indonesia utilize information technology [5], one of which is the Permata Ngijo Savings and Loans Cooperative. 
The Permata Ngijo Savings and Loans Cooperative is a savings and loan cooperative pioneered by family welfare empowerment women (PKK) which has 30 active members. The purpose of the savings and loan cooperative operated by the cooperative is to help residents, especially the local RW, easily borrow money without collateral, fight the loan shark system, avoid usury, improve contracts, and avoid consumptive borrowing behavior. The cooperative system is expected to be more transparent by increasing a sense of trust, mutual harmony, and friendship. The data processing system that is currently being run by several cooperatives still uses conventional systems that still use bookkeeping media or use Microsoft Excel. The impact is frequent errors in recording member data, savings data, loan data, and payment data to reporting. The utilization and application of information technology that is integrated with information sources and user activities involved can produce information systems for users in the business world. With the development of information systems, many companies and organizations have changed a simple recording system into a recording system using an application. So that information system support is needed to facilitate accurate data processing, time efficiency, and more optimal resources [7].

Research on information systems and cooperative information technology has been raised as a research topic by several previous researchers. The literature review presents previous studies related to cooperative information systems that can be used as references. The first research was conducted by Caroline (2018) who created a web-based savings and loan cooperative information system that was implemented in the Cempaka cooperative. The purpose of this research is to build an information system using a prototype system developer method. The system design used is unified modeling language (UML) and/the hypertext preprocessor (PHP) encoding. The programming language and data storage used is MySQL with black-box testing as a system test. This research produces a system consisting of several member data management processes, savings and loan transactions, cash withdrawal transactions, and loan installment transactions [1]. Research conducted by Pane [5] is to create an information system for a savings and loan cooperative system that is also web-based which is implemented at the Pancuran Hidup Credit Union. The purpose of this research is to create a savings and loan information system to facilitate employees in managing data and savings and loan transactions. The method used is the waterfall system development life cycle (SDLC) analysis. SDLC model or the so-called linear sequential model. The web-based savings and loan information system at the Union of Living Credit Pekanbaru which can make it easier to make reports and produce more accurate data [5]. The next research by Andreansyah [8] discusses the development of web-based savings and loan applications. The method implemented is the incremental model. The test was conducted based on the usability factor of ISO $9126-3$ by 31 respondents. This application is very useful in helping to calculate employee salaries [8].

In this study, an android application was developed that was applied to the Permata Ngijo Loan and Savings Cooperative for officers and members of the cooperative. The goal is to create a system that can provide convenience for cooperative officers in recording data, processing data, and making reports that are integrated between data so that the information produced is transparent and can be used as support in the decision-making process. Given the android application is a mobile technology that has developed rapidly and has become an important part of people's daily lives [9]-[14] and has an important role in enhancing strategic innovations [15]. Mobile-based application development can be accessed easily and can display information as needed in a user-friendly display [16]. This application has featured in the form of savings records, loan data, installment history, and notifications with an additional group chat feature as a transparent communication medium to make it easier for members to monitor and obtain information. Application testing includes black box testing and application usability testing which refers to ISO 9241:11 (1998). ISO 9241:11 (1998) describes the level of usability of a product to achieve goals that are effective, efficient, and satisfying product users [17]-[20].

\section{RESEARCH METHOD}

The research method section discusses the stages of research. This section also discusses system block diagrams, data flow diagrams (DFD), and flowchart systems of savings and loan cooperative application. The steps taken in this study are shown in Figure 1. The application stage begins by visiting the target cooperative whose system is still using the conventional system. Interviews with cooperative managers to find out the needs of cooperative managers and their members in the cooperative operational service process. Based on the interview, the application can be built with the stages of preparing the requirements, application design, coding, testing, and implementation with build coding to proceed to application testing. Tests include black-box testing and usability testing which refers to ISO 9241:11 (1998). 


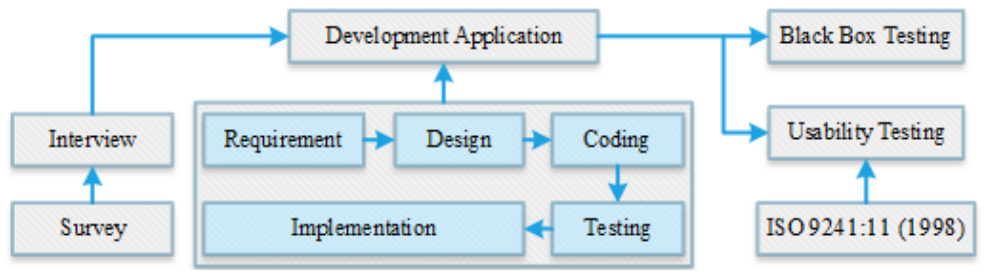

Figure 1. Application research stages

\subsection{System block diagram}

The system that was built provides mobility access in conducting transactions by members and administrators who are implemented in the android application. The concept of the savings and loan cooperative application that was built is described in the system block diagram shown in Figure 2. Based on the system block diagram in Figure 2, the function of each component of the first diagram is a database that contains a collection of member data and savings and loan transactions that are stored systematically and processed using an application. The database stores data and the application displays member data, savings data, loan data, installment data, and savings data. The database used is MySQL with the hypertext preprocessor (PHP) programming language to read and process the data in the database. Administrators act as controllers by accessing administrator-specific applications. In the application there is a process of receiving member requests, accepting loan applications, accepting savings applications, adding, and accumulating borrower payments which can then be viewed on the member-only application. Cooperative members are registered members and already have an account on the application. Each member can apply for loans and savings, get information on installment payments, total savings and loans information, and history of obtaining each loan or savings and can communicate with admins and other members to conduct deliberations or get information on the development of the cooperative through chat rooms.

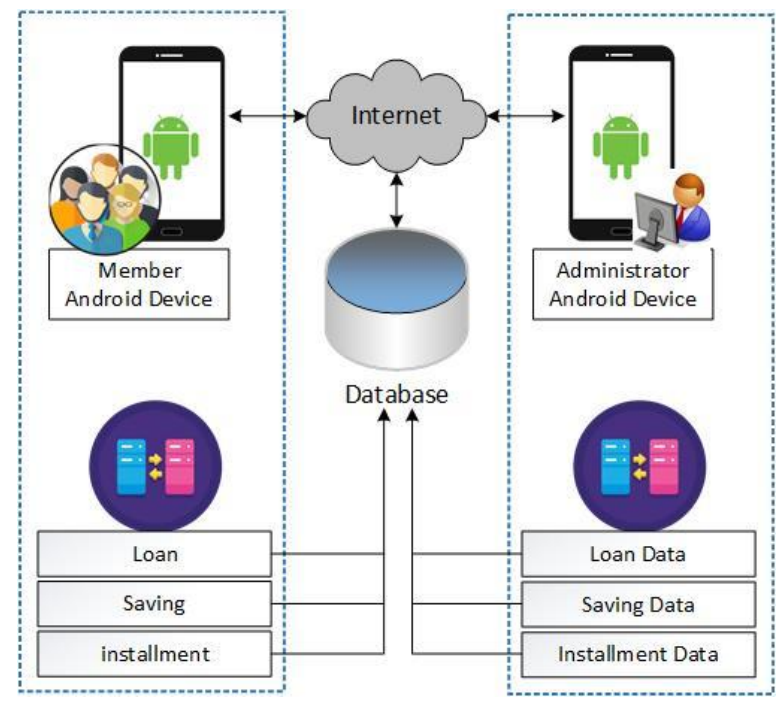

Figure 2. Savings and loan cooperative system block diagram

\subsection{Data flow diagram application system}

DFD is a graphical representation that describes the flow of information and the transformation of information that is applied as data that flows from input and output. Data flow in DFD is given the symbol of an arrow. Data flows between processes, data stores, and external entities [15]-[21]. DFD can be used to represent a system or software at several levels of abstraction. The following is the planning of level 0 DFD in the Savings and Loans cooperative application. Based on Figure 3, the external entities of the application are administrator, members, and visitors. The data can be processed by the system and entered into a database that is monitored by the admin and then members can view info on savings, installments, loans, and cash as well as information on the development of the cooperative system being managed. 


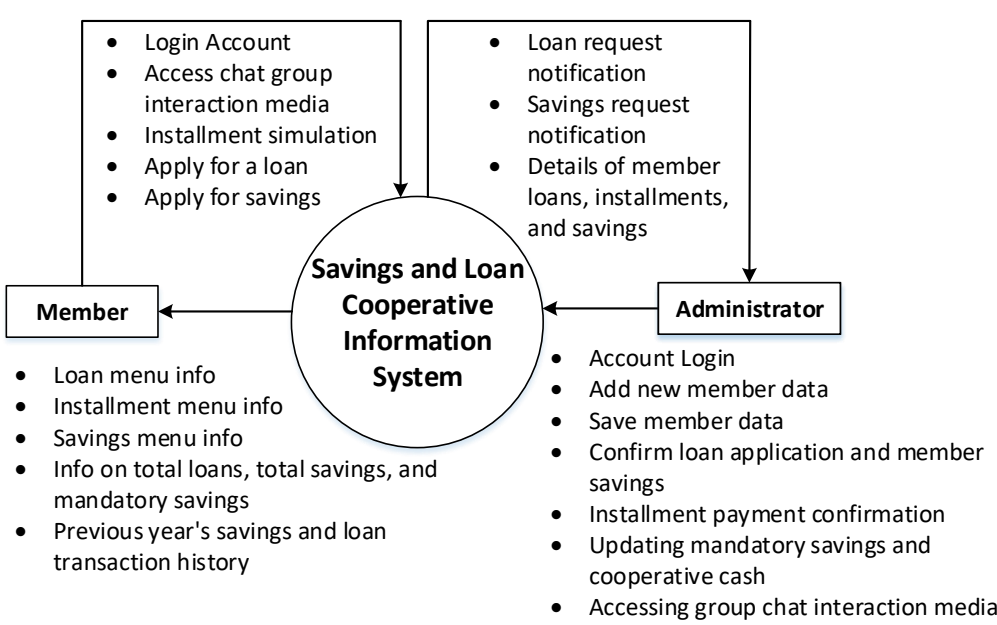

Figure 3. DFD level 0

\subsection{System flowchart}

The flowchart for the activities and menus contained in the member application and admin application will be explained in Figure 4. The first, $\log$ in to the account. If you don't have an account, you will be directed to register an account first. Applications are divided into administrator and member applications. In the member application, users who have registered or logged in can apply for loans and savings. If a member is going to make a loan transaction, the user will apply for a loan application and enter a nominal based on need, perform installment simulations, view loan installment payment information, view information on savings and loan transaction reports, view the history of savings and loan transactions for the previous period, and can check savings and loan activities. The application also provides a chat feature for communication media between members and administrators. The administrator can manage the finances of the members. When members make transactions, the admin serves as the party who reports the data and updates the data that has been inputted.
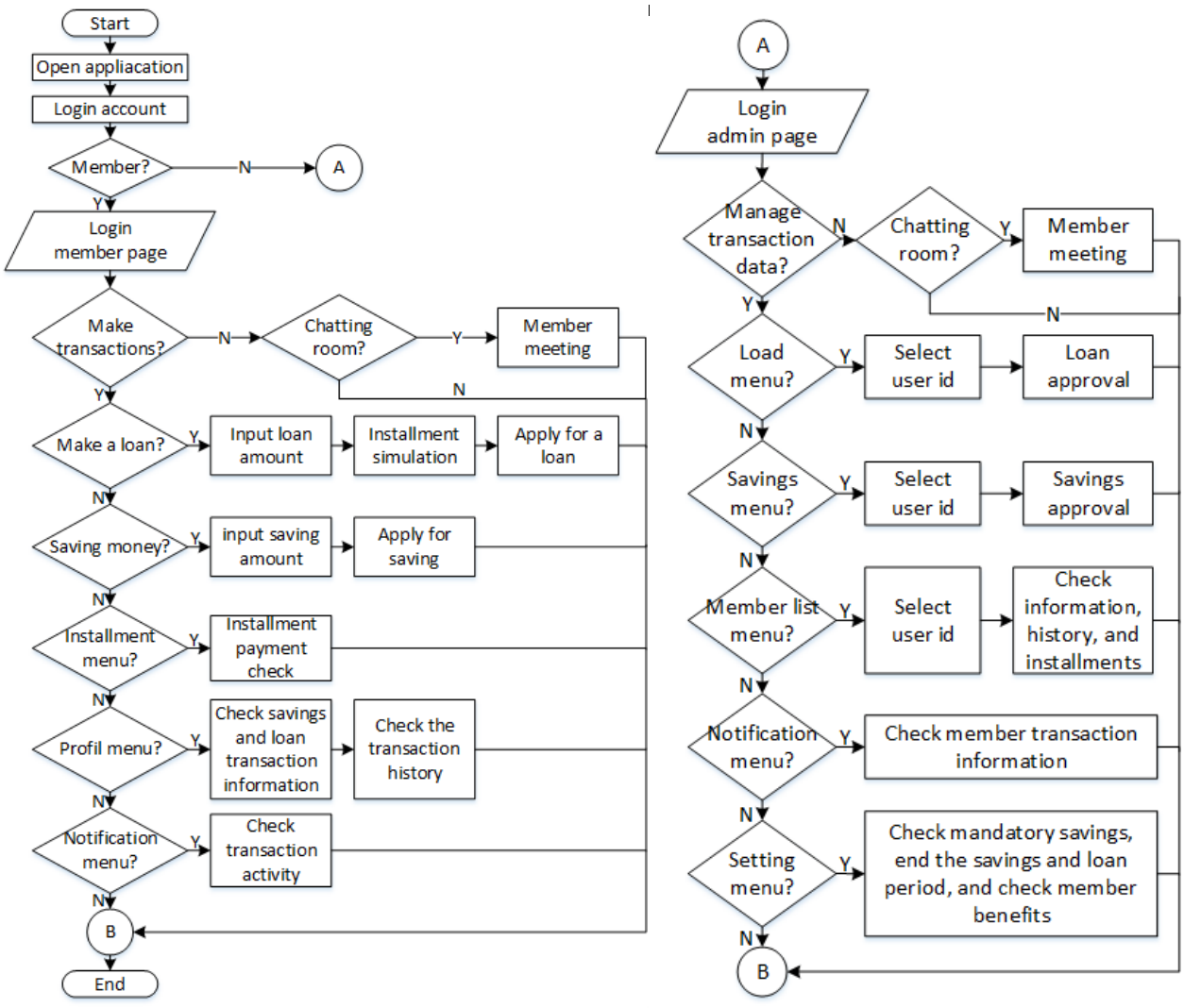

Figure 4. Flowchart system 


\section{RESULTS AND DISCUSSION}

The results that will be displayed include application interface results, black box testing, system usability, and load testing.

\subsection{Application interface results}

In the administrator application, the first, log in to an account as shown in Figure 5 (a). Then it will be entered on the homepage containing a description of the active transaction period, the number of member requests to make loans, and savings. In addition to the homepage, the administrator contains a menu of member savings lists, member loan lists, and member lists as shown in Figure 5 (b). Administrators can also add members by inputting new member data as shown in Figure 5 (c).

In the member application, the first thing that must be done is the same as the administrator, namely logging in to the account as shown in Figure 6 (a). After successful login, you will enter the homepage which contains information about the active period and the simulation of monthly installments that must be paid as well as the total to be paid by filling in the nominal amount of money to be borrowed and the selected installment amount as shown in Figure 6 (b). On the member's side, besides the homepage, there is a savings menu to enter the nominal amount of money to be saved, a loan menu to enter the amount of money to be borrowed, and a member menu which contains the member's information as shown in Figure 6 (c).

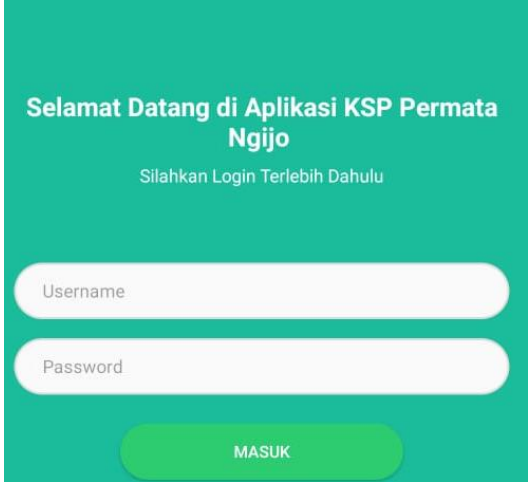

(a)

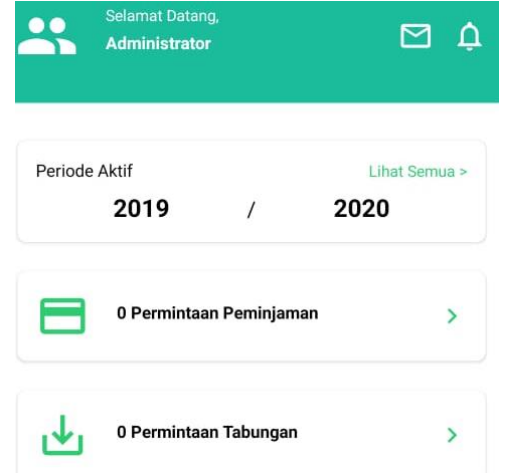

(b)

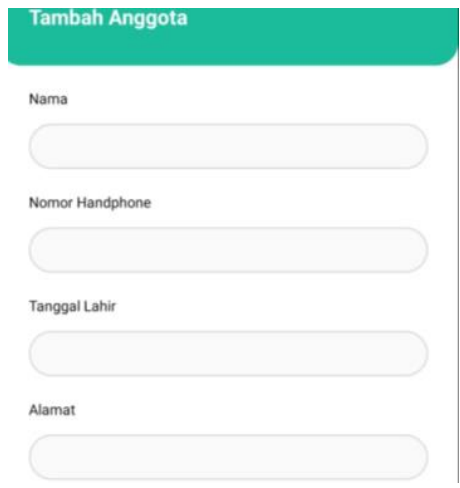

(c)

Figure 5. Application interface on administrator, (a) login display, (b) display of menus on the administrator, (c) add member view

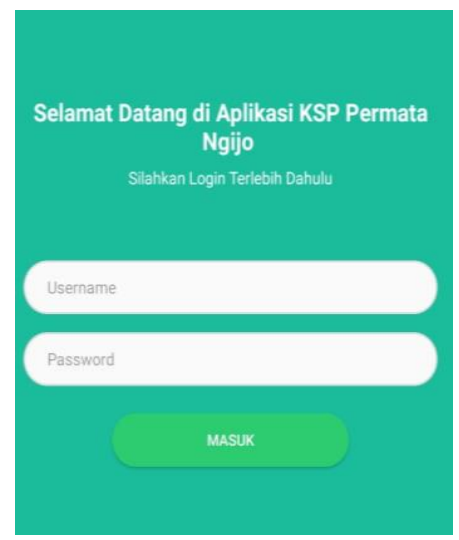

(a)

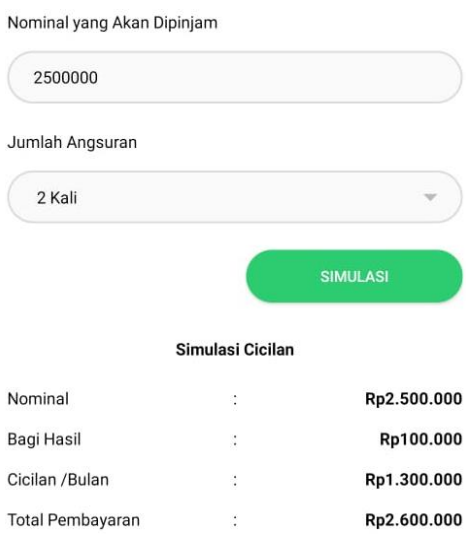

(b)

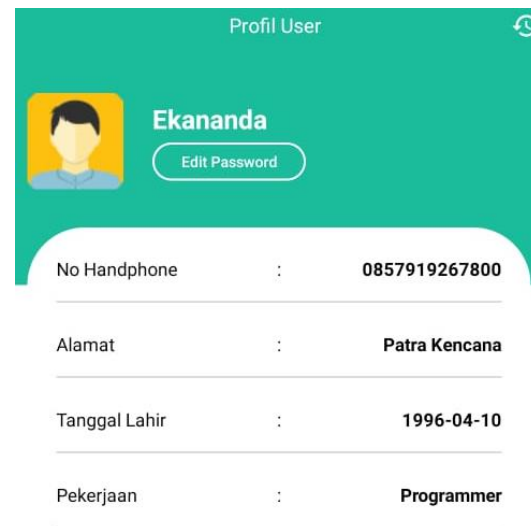

(c)

Figure 6. Application interface on member, (a) login display, (b) simulation installment on "beranda" and display menus on member, (c) display of member data information

\subsection{The black box testing}

The black box method is a software testing method whether the application components meet the functional specifications and without source code [13], [22], [23]. One way to test the system is to test the system by entering correct and incorrect data. The results of the black box testing on the administrator application are shown in Table 1 and the member allocation is shown in Table 2. The functions contained in the administrator and member application can run and function as planned. This is evident from the actual output displayed is by the expected output. 
Table 1. The results of the black box test on the administrator application

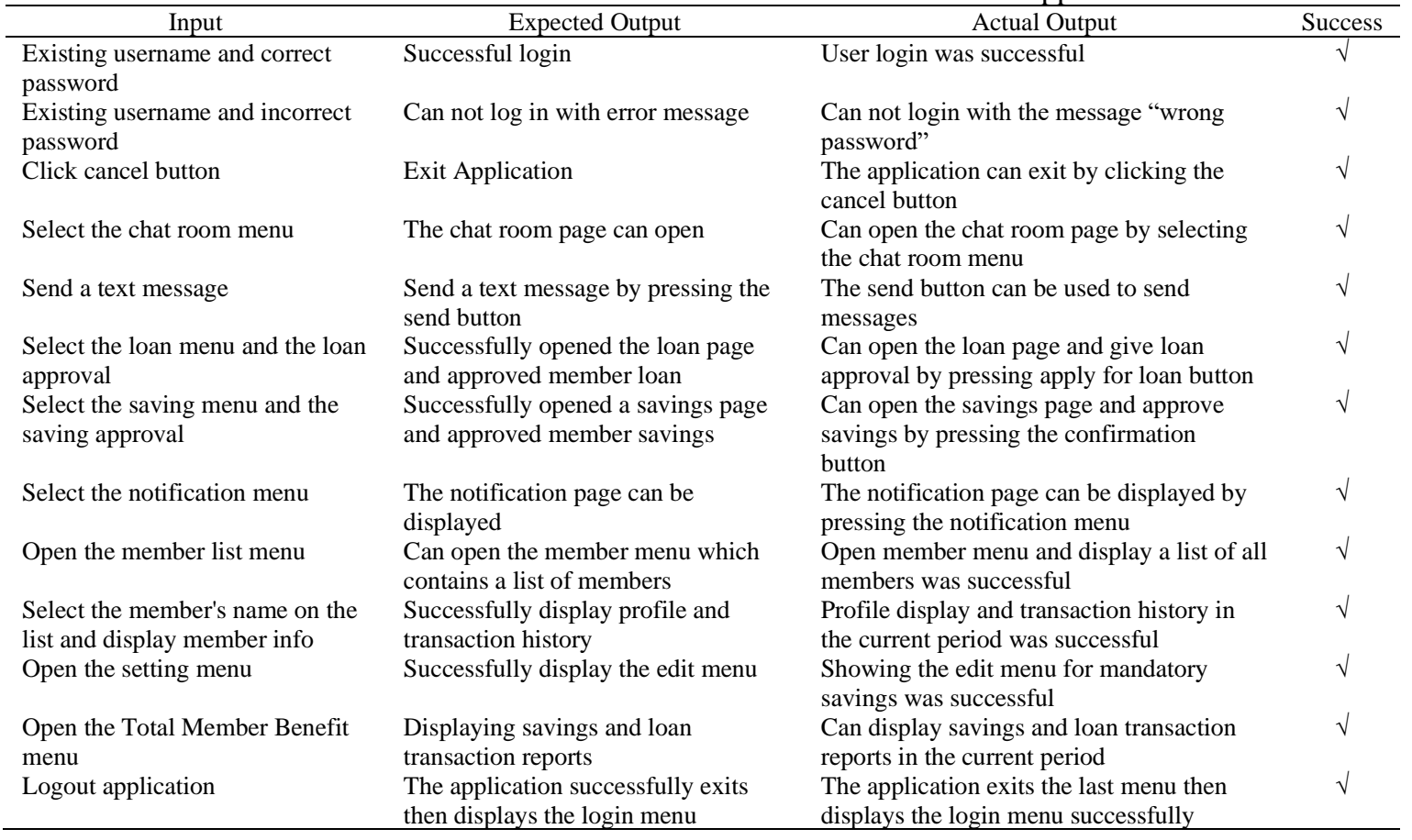

Table 2. The results of the black box test on the administrator application

\begin{tabular}{|c|c|c|c|}
\hline Input & Expected Output & Actual Output & Success \\
\hline $\begin{array}{l}\text { Existing username and } \\
\text { correct password }\end{array}$ & Successful log in & User login was successful & $\sqrt{ }$ \\
\hline $\begin{array}{l}\text { Existing username and } \\
\text { incorrect password }\end{array}$ & Cannot log in with error message & Cannot login with the message "wrong password" & $\sqrt{ }$ \\
\hline $\begin{array}{l}\text { Open register a new } \\
\text { account and fill in the } \\
\text { member's data }\end{array}$ & $\begin{array}{l}\text { Users can enter the registration page } \\
\text { and can be registered as a member }\end{array}$ & $\begin{array}{l}\text { The user has successfully entered the register } \\
\text { page and can be registered as a member }\end{array}$ & $\sqrt{ }$ \\
\hline $\begin{array}{l}\text { Select the chat menu } \\
\text { and send a message }\end{array}$ & $\begin{array}{l}\text { Enter the chat menu, can send and } \\
\text { display messages }\end{array}$ & $\begin{array}{l}\text { Enter the chat menu, can send and display } \\
\text { messages was successful }\end{array}$ & $\sqrt{ }$ \\
\hline $\begin{array}{l}\text { Select the loan menu, } \\
\text { perform installment } \\
\text { simulations, and apply } \\
\text { for a loan }\end{array}$ & $\begin{array}{l}\text { Enter the loan menu, display the } \\
\text { installments that must be paid based } \\
\text { on the number of installments entered, } \\
\text { and the loan was successful with a } \\
\text { successful message }\end{array}$ & $\begin{array}{l}\text { Enter the loan menu, display the installments that } \\
\text { must be paid based on the number of installments } \\
\text { entered, and the loan was successfully submitted } \\
\text { with the message "loan submitted successfully" }\end{array}$ & $\sqrt{ }$ \\
\hline $\begin{array}{l}\text { Select the savings } \\
\text { menu, open the add } \\
\text { balance menu, and } \\
\text { save savings }\end{array}$ & $\begin{array}{l}\text { Users can see the amount of savings } \\
\text { and mandatory savings, can enter the } \\
\text { nominal savings, and can save the } \\
\text { nominal savings by pressing the save } \\
\text { button. }\end{array}$ & $\begin{array}{l}\text { The user has succeeded in seeing the amount of } \\
\text { savings and mandatory savings, has successfully } \\
\text { entered the nominal savings, and has succeeded } \\
\text { in saving the nominal savings by pressing the } \\
\text { save button }\end{array}$ & $\sqrt{ }$ \\
\hline $\begin{array}{l}\text { Select menu } \\
\text { installment }\end{array}$ & $\begin{array}{l}\text { Loan ID information and installment } \\
\text { payment information }\end{array}$ & $\begin{array}{l}\text { The user has successfully seen the loan ID } \\
\text { information and installment payment information }\end{array}$ & $\sqrt{ }$ \\
\hline $\begin{array}{l}\text { Select profile menu, } \\
\text { info menu, and display } \\
\text { savings and loan } \\
\text { history }\end{array}$ & $\begin{array}{l}\text { Successfully view personal data, } \\
\text { savings and loan info, and view } \\
\text { savings and loan history }\end{array}$ & $\begin{array}{l}\text { Users successfully view personal data, savings } \\
\text { and loan info, and view savings and loan history }\end{array}$ & $\sqrt{ }$ \\
\hline $\begin{array}{l}\text { Select notifications } \\
\text { menu }\end{array}$ & $\begin{array}{l}\text { The user receives an administrator } \\
\text { confirmation notification for loan and } \\
\text { savings approval }\end{array}$ & $\begin{array}{l}\text { The user has successfully received an admin } \\
\text { confirmation notification for loan and savings } \\
\text { approval }\end{array}$ & $\sqrt{ }$ \\
\hline
\end{tabular}

\subsection{System usability testing on respondents}

Testing of the application system on respondents is carried out to measure the level of effectiveness of the application by collecting respondents. The definition of usability according to ISO 9241:11 (1998) is the extent to which a product can be used by certain users to achieve the set targets with effectiveness, efficiency and achieve user satisfaction [24], [25]. The measurement used to test the savings and loan cooperative application system uses a two-point Likert scale that contains valid and invalid. There are 25 respondents in this KSP application. Testing of administrator applications on respondents is shown in Table 3 and member applications are shown in Table 4. 
Table 3. Testing the administrator application on respondents

\begin{tabular}{llcccc}
\hline \multicolumn{1}{c}{ Menu } & Sub Menu & Number of Test Cases & Number of Valid & Number of Invalid & Valid Percentage \\
\hline Dashboard Admin & Login & 25 & 25 & 0 & $100 \%$ \\
Admin Application Menu & Chat rooms & 25 & 22 & 3 & 0 \\
& Loan & 25 & 25 & 0 & $100 \%$ \\
& Saving & 25 & 25 & 0 & $100 \%$ \\
& Notifications & 25 & 25 & 0 & $100 \%$ \\
& User list & 25 & 25 & 0 & $100 \%$ \\
& Setting & 25 & 25 & 0 & $100 \%$ \\
& Installment & 25 & 25 & 0 & $100 \%$ \\
& History & 25 & 25 & 0 & $100 \%$ \\
& Other menus & 25 & & & $00 \%$ \\
\hline
\end{tabular}

Table 4. Testing the member application on respondents

\begin{tabular}{|c|c|c|c|c|c|}
\hline Menu & Sub Menu & Number of Test Cases & Number of Valid & Number of Invalid & Valid Percentage \\
\hline \multirow[t]{2}{*}{ Dashboard Member } & Login & 25 & 25 & 0 & $100 \%$ \\
\hline & Register & 25 & 22 & 3 & $88 \%$ \\
\hline \multirow{2}{*}{ Member Application } & Chat rooms & 25 & 21 & 4 & $84 \%$ \\
\hline & Loan & 25 & 25 & 0 & $100 \%$ \\
\hline \multirow[t]{7}{*}{ Menu } & Saving & 25 & 25 & 0 & $100 \%$ \\
\hline & Loan simulation & 25 & 25 & 0 & $100 \%$ \\
\hline & Notifications & 25 & 25 & 0 & $100 \%$ \\
\hline & Profile & 25 & 25 & 0 & $100 \%$ \\
\hline & Info & 25 & 25 & 0 & $100 \%$ \\
\hline & Installment & 25 & 25 & 0 & $100 \%$ \\
\hline & History & 25 & 25 & 0 & $100 \%$ \\
\hline
\end{tabular}

Based on Table 3 and Table 4, in the administrator application, the results of testing the chat room menu have the lowest success rate of $88 \%$ found in the chatroom menu. Problems in chat rooms are "no response" or "error or username doesn't exist" or commonly called force close. In the member application, the results of the chatroom menu experiment show the lowest success rate with a success percentage rate of $84 \%$. In addition, the register menu also has a success percentage of $88 \%$. So that the average success rate obtained by the admin application is $98 \%$ and the member application has a success rate of $97.72 \%$. Several things that cause android applications to stop suddenly are the accumulation of cache files on the user's Android smartphone, full android RAM, unstable network, and incompatible APIs on android.

\section{CONCLUSION}

In this research, the development of an Android-based KSP Permata Ngijo application has been built with the stages of system design, implementation, and testing. Based on the results obtained from testing, it can be seen that on the administrator side the system can be used to manage member data, savings and loan transactions, loan installment transactions, member data reports, and savings and loan reports. On the member's side, the system can be used to view deposits and loans from the member and can see a simulation of the installments that must be paid according to the number of installments. This application still uses a simple application security JSON web token (JWT) to authenticate the system and exchange information. JWT secures information into a claim that is encoded into JSON form. The user will enter a username and password which will be sent to the system. The system validates whether the user is registered. When the user is registered, a JWT token will be generated which will be used to access the permitted data. If the JWT does not exist, the user will not be able to access the data. Further research will develop applications by adding a better system security system to protect all data contained in the application.

\section{ACKNOWLEDGEMENT}

Thank UPT P2M State Polytechnic of Malang for the funds that have been provided through the Regular DIPA fund.

\section{REFERENCES}

[1] E. Caroline and M. Ziveria, "Saving and Loan Information System of Cempaka Cooperative Web Based," 20187 th International Conference on Reliability, Infocom Technologies and Optimization (Trends and Future Directions) (ICRITO), 2018, pp. 784-791, doi: 10.1109/ICRITO.2018.8748603.

[2] M. R. H. Amal and A. Kartika, "BENEFICIAL OWNERSHIP ARRANGEMENTS IN SAVING LOAN COOPERATIVE AS A PREVENTIVE ATTEMPT TO THE CRIME OF MONEY LAUNDERING," European Journal of Social Sciences Studies, vol. 6, no. 2, pp. 163-177, 2021, doi: 10.46827/ejsss.v6i2.1023. 
[3] M. B. Sibuea and F. A. Sibuea, "Effectiveness of Saving and Loan Activities of Islamic Cooperation in Deli Serdang," in Proceedings of the 7th International Conference on Multidisciplinary Research (ICMR 2018), 2018, pp. 464-471, 2020, doi: 10.5220/0008889104640471.

[4] N. Khamis, K. Kong and K. Li, "User experience evaluation for a bus tracking apps in smart campus initiative," Bulletin of Electrical Engineering and Informatics, vol. 10, no. 4, pp. 2254-2262, August 2021, doi: 10.11591/eei.v10i4.3112.

[5] E. S. Pane, "Save And Loan Credit Information System Based On Web," Journal of Applied Engineering and Technological Science (JAETS), vol. 2, no. 1, pp. 14-20, 2020, doi: 10.37385/jaets.v2i1.166.

[6] P. Yadnya and H. B. Suprasto, "Success implementation of online technology information system on market cooperative kumbasari denpasar," International research journal of management, IT and social sciences, vol. 6, no. 6, pp. 135-145, 2019, doi: 10.21744/irjmis.v6n6.780.

[7] N. K. D. Hariyanti, I. G. N. Sanjaya, I. P. Sutawinaya and I. G. P. F. P. Sudhana, "Conceptual Model for Adoption of Mobile Banking Technology in Savings and Loans Cooperatives," International Conference on Applied Science and Technology on Social Science (ICAST-SS 2020), Atlantis Press, vol. 544, pp. 114-120, 2021, doi: 10.2991/assehr.k.210424.023.

[8] A. Andreansyah, A. Rachman and R. Rizkiana, "Implementation of Incremental Models on Development of WebBased Loan Cooperative Applications," International Journal of Education, Science, Technology and Engineering, vol. 3, no. 1, pp. 26-34, 2020, doi: 10.36079/lamintang.ijeste-0301.105.

[9] M. Gasah, A. Baharum, N. H. M. Zain, S. Halamy, R. Hanapi and N. A. M. Noor, "Evaluation of positive emotion in children mobile learning application," Bulletin of Electrical Engineering and Informatics, vol. 9, no. 2, pp. 818826, April 2020, doi: 10.11591/eei.v9i2.2073.

[10] M. R. Bin Mohamad Razali, S. Ahmad and N. M. Diah, "Collaborative filtering content for parental control in mobile application chatting," Bulletin of Electrical Engineering and Informatics, vol. 8, no. 4, pp. 1517-1524, December 2019, doi: 10.11591/eei.v8i4.1634.

[11] M. Sarosa, D. Febiyanti and H. Darmono, "Design and implementation of voice time, time indicator application for diabetic retinopathy patients," International Journal of Interactive Mobile Technologies, vol. 14, no. 2, pp. 144159, 2020, doi: 10.3991/ijim.v14i02.11436.

[12] P. E. Masudia, M. Sarosa, A. E. Rakhmania, U. Z. Muhammad and E. S. Putri, "Saving The Vegetable Peddler (Mlijo) with Information Technology," 2018 Third International Conference on Informatics and Computing (ICIC), 2018, pp. 1-6, doi: 10.1109/IAC.2018.8780425.

[13] M. L. Larrea, "Black-Box Testing Technique for Information Visualization. Sequencing Constraints with LowLevel Interactions," Journal of Computer Science \& Technology, vol. 17, no. 1, pp. 37-48, 2017.

[14] A. Romdhana and A. Merlo, "Keynote: ARES: A Deep Reinforcement Learning Tool for Black-Box Testing of Android Apps," 2021 IEEE International Conference on Pervasive Computing and Communications Workshops and other Affiliated Events (PerCom Workshops), 2021, p. 173, doi: 10.1109/PerComWorkshops51409.2021.9431072.

[15] J. S. Suroso and Y. Wahjudi, "ANALYSIS OF FACTORS AFFECTING SATISFACTION AND LOYALTY OF DIGITAL LOAN CUSTOMER AT PT,” vol. 99, no. 11, pp. 2617-2631, June 2021.

[16] B. Noranita, D. M. K. Nugraheni, M. I. Fitriyani and Y. Nurhayati, "Business architecture and information system architecture design in savings and payment unit Koperasi Pegawai Republik Indonesia (KPRI) Diponegoro University using TOGAF 9 framework," Journal of Physics: Conference Series, IOP Publishing, vol. 1943, no. 1, p. 012105, 2021, doi: 10.1088/1742-6596/1943/1/012105.

[17] H. Moghaddasi, R. Rabiei, F. Asadi and N. Ostvan, "Evaluation of nursing information systems: Application of usability aspects in the development of systems," Healthcare informatics research, vol. 23, no. 2, pp. 101-108, 2017, doi: 10.4258/hir.2017.23.2.101.

[18] Y. F. Nova and T. Yunitasari, "Usability Analysis on ISO 9241-11 Based Bibit and Bareksa Mutual Software Application Using Partial Least Square (PLS)," International Research Journal of Advanced Engineering and Science, vol. 6, no. 2, pp. 45-48, 2021.

[19] T. D. Susanto, A. I. Prasetyo and H. M. Astuti, "Web usability evaluation on BloobIS website by using hallway usability testing method and ISO 9241:11,” Journal of Physics: Conference Series, IOP Publishing, vol. 974, no. 1, p. 012043, March 2018, doi: 10.1088/1742-6596/974/1/012043.

[20] L. T. Hui, L. S. Hoe and H. Ismail, "Children Video Puzzle Interaction Framework Based on Multi-Touch Technology: An ISO 9241-11: 2018 Approach," International Journal of Advanced Research in Education and Society, vol. 2, no. 2, pp. 5569, June 2020. [Online]. Available: http://myjms.moe.gov.my/index.php/ijares/article/view/9655.

[21] H. Y. Chong and A. Diamantopoulos, "Integrating advanced technologies to uphold security of payment: Data flow diagram," Automation in construction, vol. 114, p. 103158, 2020, doi: 10.1016/j.autcon.2020.103158.

[22] S. Rawat and R. Kumar, "Direct-Indirect Link Matrix: A Black Box Testing Technique for Component-Based Software," International Journal of Information Technology Project Management (IJITPM), vol. 11, no. 4, pp. 5669, 2020, doi: 10.4018/IJITPM.2020100105.

[23] R. Pan, Z. Zhang, X. Li, K. Chakrabarty and X. Gu, "Black-Box Test-Coverage Analysis and Test-Cost Reduction Based on a Bayesian Network Model," 2019 IEEE 37th VLSI Test Symposium (VTS), 2019, pp. 1-6, doi: 10.1109/VTS.2019.8758639.

[24] N. A. N. Ahmad, N. I. M. Hamid and A. M. Lokman, "Performing Usability Evaluation on Multi-Platform Based Application for Efficiency, Effectiveness and Satisfaction Enhancement," International Journal of Interactive Mobile Technologies, vol. 15, no. 10, pp. 103-117, 2021, doi: 10.3991/ijim.v15i10.20429.

[25] C. S. Dietlein and O. L. Bock, "Development of a usability scale based on the three ISO 9241-11 categories 'effectiveness,' 'efficacy' and 'satisfaction': a technical note," Accreditation and Quality Assurance, vol. 24, no. 3, pp. 181-189, 2019, doi: 10.1007/s00769-018-01368-2. 